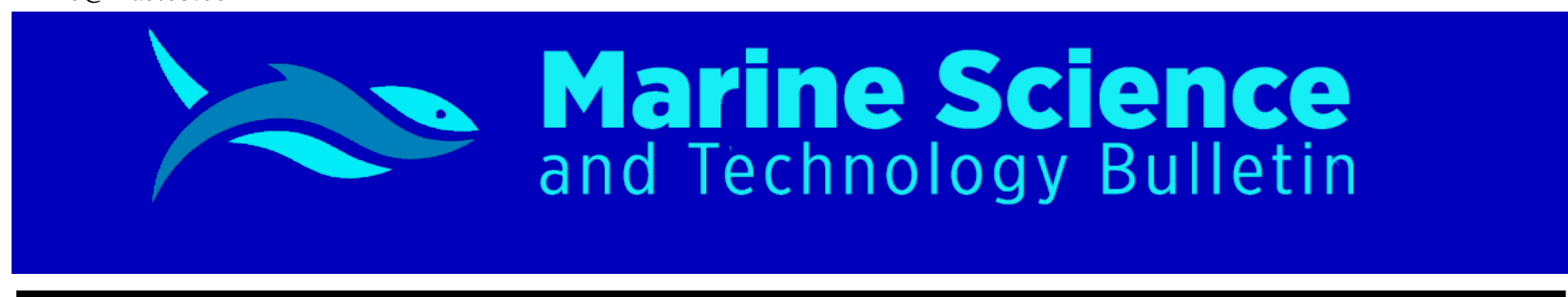

RESEARCH ARTICLE

\title{
Extraction and characterization of polyhydroxybutyrate (PHB) from Bacillus flexus MHO57386.1 isolated from marine sponge Oceanopia arenosa (Rao, 1941)
}

Deepa Aryaraj $^{1^{*}}$ (D) Vasantha Subramonian Pramitha ${ }^{1}$

${ }^{1}$ Department of Aquatic Biology and Fisheries, University of Kerala, Thiruvananthapuram 695 581, Kerala, India

\begin{tabular}{|c|c|}
\hline A R T I C L E I N F O & A B S T R A C T \\
\hline Article History: & Polyhydroxybutyrate (PHB) is the most widely studied biodegradable plastic that does not release \\
\hline Received: 28.11 .2020 & any toxins or residues in the environment like petroleum based plastics. This work has been \\
\hline Received in revised form: 02.01.2021 & undertaken to screen PHB accumulating microorganisms from marine sponges and a total of sixteen \\
\hline Accepted: 10.01 .2021 & isolates were collected and purified. Screening of isolated strains was done by Nile blue staining and \\
\hline Available online: 07.02 .2021 & observed under Leica LSCM to confirm the production of PHB. Yellow pigmented AB8a isolate from \\
\hline Keywords: & Oceanopia arenosa scored positive for $\mathrm{PHB}$ accumulation and subjected to morphological, \\
\hline Bacillus flexus & biochemical and phylogenetic characterization. The biopolymer was extracted by dispersion of \\
\hline Biopolymers & sodium hypochlorite and chloroform solution and characterized by FT-IR and $1 \mathrm{H}$ NMR for the \\
\hline FTIR & confirmation as PHB. The highest $\mathrm{PHB}$ production $(70.25 \% / 100 \mathrm{ml})$ was achieved at $\mathrm{pH} 7.0$ by \\
\hline${ }^{1} H N M R$ & applying dextrose as medium at incubation temperature $30^{\circ} \mathrm{C}$ and $150 \mathrm{rpm}$ agitation speed. The FTIR \\
\hline & spectrum of the PHB sample showed major peaks at 3457, 1692, 1550, 1454, 1420, 1190 and 1050 \\
\hline Nile blue & $\mathrm{cm}^{-1}$, whereas the remaining peaks are closely laid between $3450 \mathrm{~cm}^{-1}$ and $600 \mathrm{~cm}^{-1} .{ }^{1} \mathrm{H} \mathrm{NMR}$ \\
\hline Oceanopia arenosa & spectrum of PHA isolated from dextrose media indicated characteristic signals of PHB. The spectrum \\
\hline & also revealed the presence of three groups of signals characteristic of $\mathrm{PHB}$ by the doublet at $1.3 \mathrm{ppm}$ \\
\hline & attributed to the methyl group coupled to one proton; and the spectrum of the quadruplet at 2.57 \\
\hline & ppm, the methylene group adjacent to an asymmetric carbon atom bearing a single proton and the \\
\hline & multiplet at $5.28 \mathrm{ppm}$ indicated signals of PHB. The PHB accumulated bacterium identified as \\
\hline & Bacillus flexus strain based on characterization studies and 16S rRNA sequence analysis and \\
\hline & \\
\hline
\end{tabular}

Please cite this paper as follows:

Aryaraj, D., Pramitha, V. S. (2021). Extraction and characterization of Polyhydroxybutyrate (PHB) from Bacillus flexus MHO57386.1 isolated from marine sponge Oceanopia arenosa (Rao, 1941). Marine Science and Technology Bulletin, 10(2): 170185.

\footnotetext{
* Corresponding author

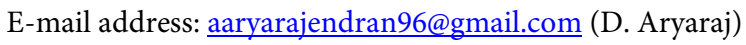




\section{Introduction}

Bacterial polyhydroxyalkanoates (PHAs) are alternates for petroleum based polymers due to their eco-friendliness, which are produced and stored by prokaryotes as cytoplasmic inclusion bodies in response to environmental stress (Castilho et al., 2009; Chen, 2009; Rehm, 2010). PHAs are polyesteric biological macromolecules and reported tobe outstanding because of their biodegradability and biocompatibility (Koller, 2018). In bacteria, PHA synthesis is triggered by stressful conditions and it can be produced industrially when the medium contains excess of carbon source with nitrogen limitation (Saharan et al., 2014). Polyhydroxybutyrate (PHB) is the most widely studied and best characterized derivative of PHA (Bhuwal et al., 2014).

Various bacteria from different environmental niches have been sourced for PHBs production and marine bacteria are rarely discovered for PHBs synthesis (Numata \& Morisaki, 2015). The majority of PHB producing bacteria was isolated from soil and activated sludge (Getachew et al., 2016). Recently, new bioresources such as marine environments were also explored regarding their potential to harbour new $\mathrm{PHB}$ producers. In general, marine ecosystems are unique habitat of microbes which are exposed to a wide variety of environmental conditions including extremes in temperature, salinity, nutrient limitation and pressure (Poli et al., 2017).

To date majority of chemicals have been identified from marine invertebrates of which sponges predominate (Lie and Zhou, 2002). Considering its pharmaceutical and drug development prospective, they are known to produce excellent resource of novel bioactive secondary metabolites (Koopmans et al., 2011). As marine sponges are usually having symbiotic relationship with different microorganisms and the marine sponge-associated symbionts have been accepted as prosperous resource of biological macromolecules, research on spongeassociated bacteria will provide remarkable new avenues for biopolymer research in future (Lie \& Zhou, 2002).

The first documented PHA producing bacterial genera was Vibrio isolated from different marine arenas (Baumann et al., 1971; Oliver \& Colwell, 1973). In marine haloarchaea, the first PHB accumulation was reported in Halobacterium sp. from Dead Sea and it was authenticated through free-fracture technique (Kirk \& Ginzburg, 1972) followed by the genera like Halococcus, Halorubrum, Haloarcula, Haloquadratum, Haloterrigena, Haloferax, Natronococcus, Natrialba and Natronobacterium which were also established as active producers of PHB (Poli et al., 2011). The notable problem in $\mathrm{PHB}$ production is the process of optimization to reduce the production cost. Hence, researchers are focusing on the selection of cheap raw materials for the production of $\mathrm{PHB}$ from marine bacteria.

The present study describes isolation and identification of bacteria having $\mathrm{PHB}$ productivity and special emphasis has been given to optimize the most significant variables such as temperature, $\mathrm{pH}$ and substrates in order to optimize the production of $\mathrm{PHB}$. The purified biopolymer was characterized by FTIR and NMR analysis by comparing with the standard PHB. Hence, the present research work has been aimed to screen marine sponge symbiotic bacteria as biological tools for production of $\mathrm{PHB}$.

\section{Material and Methods}

\section{Collection and Identification of Marine Sponges}

Marine sponges were collected from the rocky shores of Kovalam (Lat. 8'22'0.01"N; Long. 7659'48.01”E), Southern West coast of India at depth ranging from 6 to $7 \mathrm{~m}$ during November 2018 (Figure 1). Details of form, color, surface ornamentation, resiliency and biological associates were also recorded at the time of collection (Rachana et al., 2014). Sponges were identified by studying the spicule's nature using pertinent literatures and keys: Demospongiae of the Gulf of Mannar and Palk Bay (Thomas, 1986); Systema Porifera: A guide to classification of sponges (Hooper \& Van Soet, 2002); Sponguide: Guide to sponge collection and identification (Hooper, 2003) and compared it with the original description of the species in World Porifera Database (http://www.marinespecies.org/porifera).
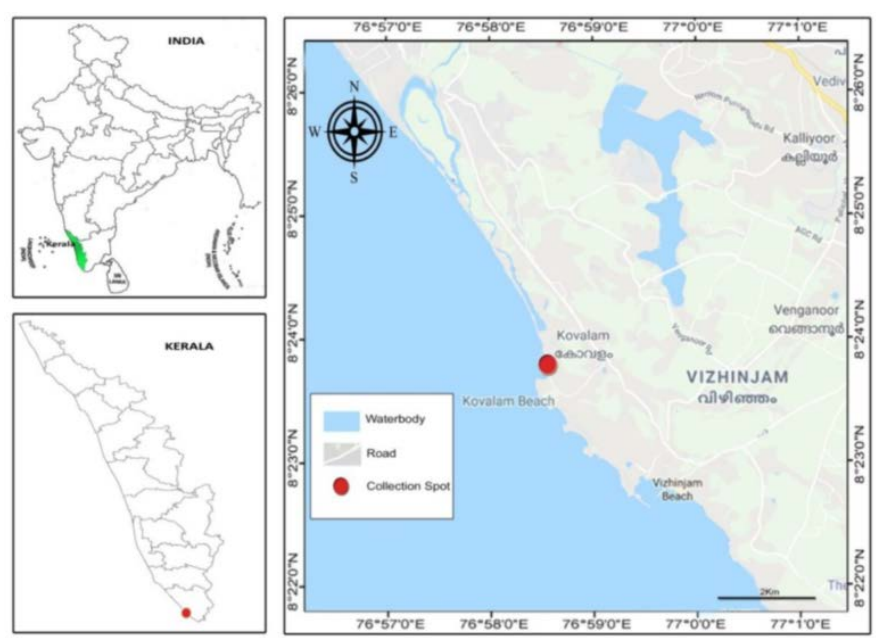

Figure 1. Map showing the collection site

\section{Isolation and Screening of Sponge Associated}

\section{Bacteria for the Production of $\mathrm{PHB}$}

The bacteria from sponges were isolated according to the method of Kim et al. (2006). Nearly $1 \mathrm{~cm} 3$ of sponge tissue was excised from the internal mesohyl area using sterile scissors in 
aseptic conditions on a sterile ceramic tile. Sterile $0.85 \%$ saline $(1 \mathrm{ml})$ was added to squeeze the specimen and homogenization continued till the sponge exudates were obtained (Selvin et al., 2009). The diluted sample was pour plated on modified culture medium of Zobell Marine Agar 2216 medium and incubated for $24 \mathrm{hrs}$ at $32^{\circ} \mathrm{C}$ (Gandhimathi et al., 2008). The morphologically distinct colonies were re-isolated and maintained on ZMA (HiMedia) at $4^{\circ} \mathrm{C}$. The pure cultures were maintained by sub-culturing.

Bacterial isolates were maintained in Minimal Davis Media and cultured for $2-3$ days at $37^{\circ} \mathrm{C}$ supplemented with dextrose ( $10 \mathrm{ml}$ of $10 \%$ in of Minimal Davis Media) as carbon source and screened by Nile Blue staining (Nile blue sulphate $90 \%$ dye content for microscopy, $1 \mu \mathrm{g} / \mathrm{ml}$ ) (Lillie, 1977) and observed under Leica LSCM - Laser Spectral Scanning Confocal Microscope, Model TCSSP 8 (Microscope Model Leica DM 18, software used-LASX). Those bacterial isolates showed bright yellowish-orange color were selected for further study (Ostle \& Holt, 1982).

\section{Characterization of Selected Bacterial Strain}

Identification of bacteria were made by morphological observations of colony, shape of bacteria, catalase test, test oxidase, test the mannitol motility and the production of compound indole, test $\mathrm{O} / \mathrm{F}$ (Oxidative/Fermentative), TSIA (Triple Sugar Iron Agar), Citrate test, Lysine, H2S, Urease, Lactose, Glucose and Bile esculin reactions.

The isolate showed significant activity was characterized using $16 \mathrm{~S}$ rRNA gene sequencing. The methodology and the primers for sequencing were adapted from Kamke et al. (2010). Genomic DNA was isolated using NucleoSpin ${ }^{\circledR}$ Tissue Kit (Macherey-Nagel, Düren, Nordrhein-Westfalen). A small portion of $16 \mathrm{~S}$ rRNA gene were amplified with the primers 16SUP-F (5-CCGAATTCGTCGACAACAGAGTTTGATCCTGGCTCAG-3') and 16S-UP-R(5-COCGGGATCCAAGCTTACGGCTACCTTGTTAOGACTT-3) (Enkicknap et al., 2006). The DNA sequence was edited and aligned using BioEdit sequence alignment editor V.7.0.9.0. (lbisBiosciences, Carlsbad, USA., Hall, 1999). Sequence similarity of specimen was done by using database GenBank (http://www.ncbi.nlm.nih.gov/genbank/). Divergence in the sequence was analyzed using the Kimura 2-Parameter distance model of MEGA (Version 6.0) (Tamura et al., 2013). Maximum likelihood tree was selected for phylogeny analysis.

Disc diffusion method (Bauer et al., 1966) was carried out on Muller Hinton agar plates (Hi-media) to determine the in vitro antibacterial susceptibility test. A $100 \mu \mathrm{l}$ of test strain (106 $\mathrm{CFU} / \mathrm{ml}$ bacteria) was spread on the Muller Hinton agar media and 25 different types of antibiotic discs were placed on the medium and were incubated for $24 \mathrm{hrs}$. After incubation at $37^{\circ} \mathrm{C}$ in incubator (ROTEK), the area of inhibition zone ( $\mathrm{mm}$ ) was determined using a Hi Antibiotic Zone Scale-C (PW-297, Hi-media).

Optimization of Cultural Parameters for PHB Production

$\mathrm{PHB}$ production were optimized by growing the culture with different $\mathrm{pH}$ ranging from $6,7,8$ and 9 and the inoculated flasks were incubated at $30^{\circ} \mathrm{C}$ at $150 \mathrm{rpm}$ for $48 \mathrm{hrs}$ and $\mathrm{PHB}$ was quantified. Effects of different temperatures upon production were optimized by incubating the cultures on a rotary shaker at 20,30 and $40^{\circ} \mathrm{C}$ and $150 \mathrm{rpm}$ for $48 \mathrm{hrs}$ and PHB was quantified. Effects of different media also optimized by dextrose, glucose and mannitol media and were sterilized at $121^{\circ} \mathrm{C}$ for 20 minutes. The inoculated flasks were incubated at $30^{\circ} \mathrm{C}$ at $150 \mathrm{rpm}$ for $48 \mathrm{hrs}$ and $\mathrm{PHB}$ was quantified.

Extraction and characterization of $\mathrm{PHB}$ from potent isolates for the extraction of $\mathrm{PHB}$, the fluorescence displayed bacterial isolates were cultured in Minimal Davis Media supplemented with Dextrose as carbon source. The culture were kept in a rotary shaker at $37^{\circ} \mathrm{C}$ and $150 \mathrm{rpm}$ for 3 days. Extraction of $\mathrm{PHB}$ was performed by sodium hypochlorite-chloroform method. After the centrifugation process the solution were appeared as three phases. The upper phase contains hypochlorite solution and the middle phase contains chloroform with cell debris. The bottom phase containing PHB with chloroform were collected and followed by extraction with hot chloroform and precipitated with ethanol and acetone (1:1). The precipitate was allowed to evaporate for dryness at $30^{\circ} \mathrm{C}$ to obtain $\mathrm{PHB}$ crystals (Singh \& Parmar, 2011).

The extracted crystals were analysed qualitatively by using Thermo Fisher Scientific Nicolet iS50 FT-IR Spectrophotometer to know the presence of different functional groups at a range of $4000-400 \mathrm{~cm}^{-1}$. IR spectra were recorded at $4 \mathrm{~cm}^{-1}$ resolution (Kansiz et al., 2000). The ${ }^{1} \mathrm{H}$ NMR spectra of extracted PHB sample was also obtained at $400 \mathrm{MHz}$ using a model Brucker Avance III HD NMR spectrometer and methanol is used as solvent. Chemical shifts (ppm) and coupling constants $(\mathrm{Hz})$ were recorded.

\section{Results}

Ten species of marine sponges were collected and based on morphological features of spicules and other specialized characters the sponges were identified as Callyspongia (Cladochalina) fibrosa (Ridley and Dendy, 1886), Callyspongia (Cladochalina) diffusa (Ridley, 1884), Tedania (Tedania) anhelans (Vio in Olivi, 1792), Myxilla (Ectyomyxilla) arenaria (Dendy, 1905), Sigmadocia carnosa (Dendy, 1889), Dysidea fragilis (Montagu, 1814), Ecionemia acervus (Bowerbank, 1864), Oceanopia arenosa (Rao, 1941), Mycale (Carmia) mytilorum (Annandale, 1914) and Mycale (Aegogropila) crassissima (Dendy, 1905) (Figure 2). 

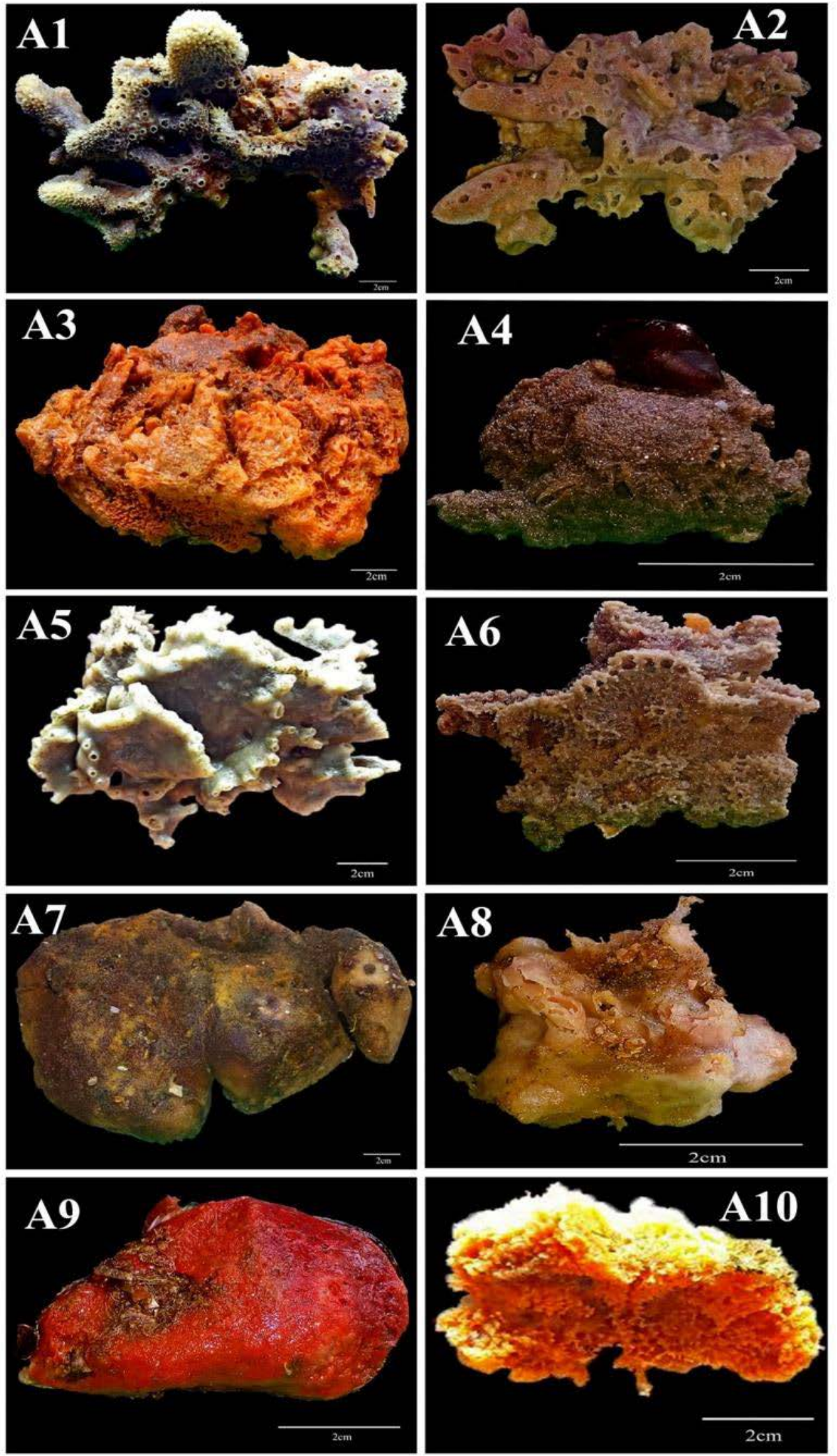

Figure 2. Collected marine sponges; A1-Callyspongia (Cladochalina) fibrosa, A2-Callyspongia (Cladochalina), A3- Tedania (Tedania) anhelans, A4- Myxilla (Ectyomyxilla) arenaria, A5- Sigmadocia carnosa, A6- Dysidea fragilis, A7- Ecionemia acervus, A8- Oceanopia arenosa, A9- Mycale (Carmia) mytilorum, A10- Mycale (Aegogropila) crassissima 


\section{Screening of isolates for $\mathrm{PHB}$ production}

The isolates obtained from marine sponges were screened for PHB production using Nile blue staining method and cultured in Minimal Davis Media (Figures 3 \& 4). Ten isolates showed growth in Minimal Davis Media were further stained with Nile blue staining and observed under Leica LSCM to confirm the production of PHB. Five isolates such as two strains each from Callyspongia diffusa (AB2a, AB2b) (Figure 5), Mycale mytillorum (AB9a, AB9b) (Figure 6) and one isolate from Oceanopia arenosa (AB8a) (Figure 7) flourish bright yellowish orange color were assumed as the $\mathrm{PHB}$ producing colonies. In this study, the $\mathrm{AB} 8 \mathrm{a} \mathrm{PHB}$ granules were fluoresced as bright orange, and it was concluded that AB8a was the best $\mathrm{PHB}$ producer with bright orange fluorescence. So the yellow pigmented AB8a isolate from Oceanopia arenosa showed high intensity was selected for further observations and study.
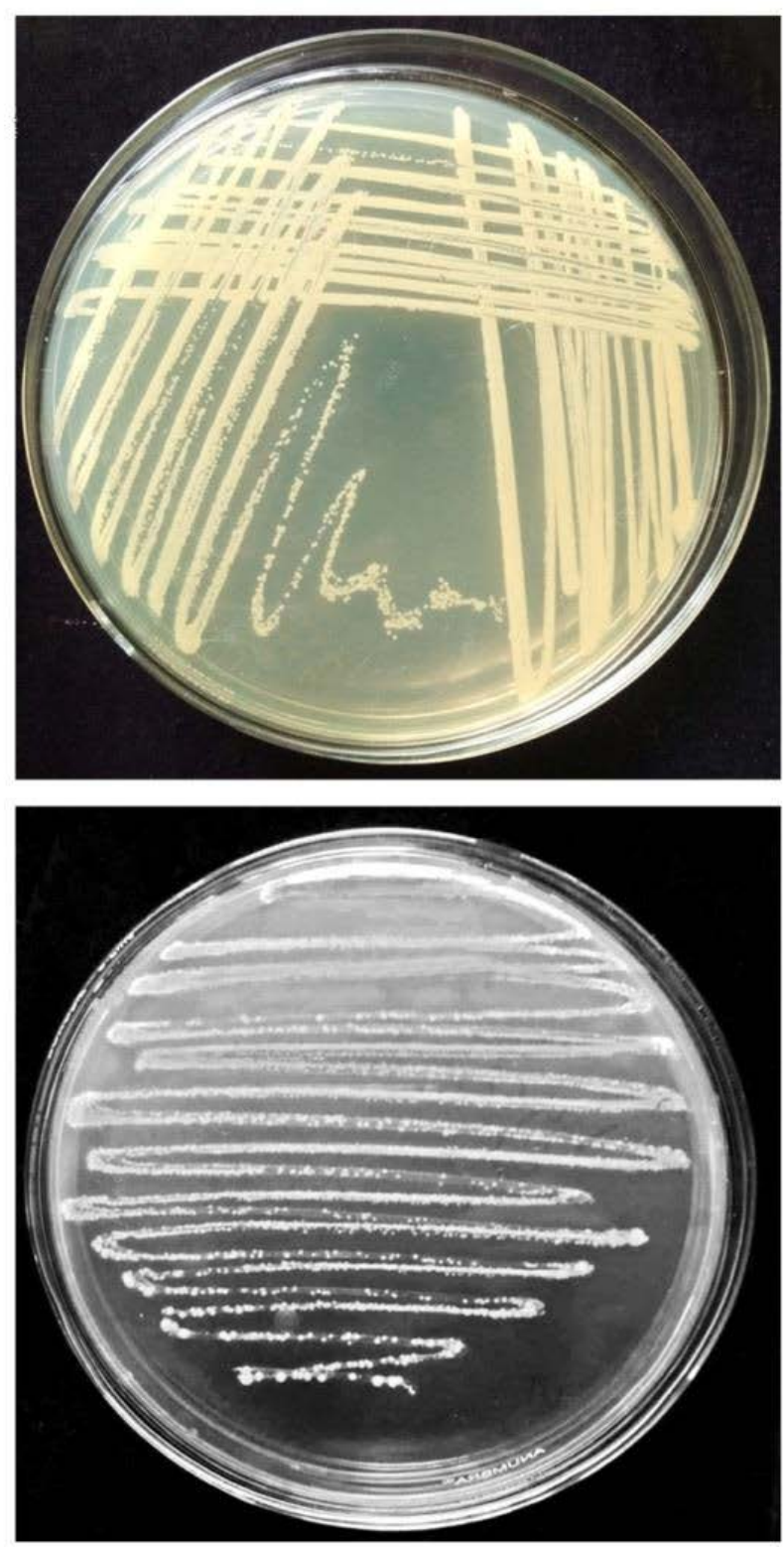
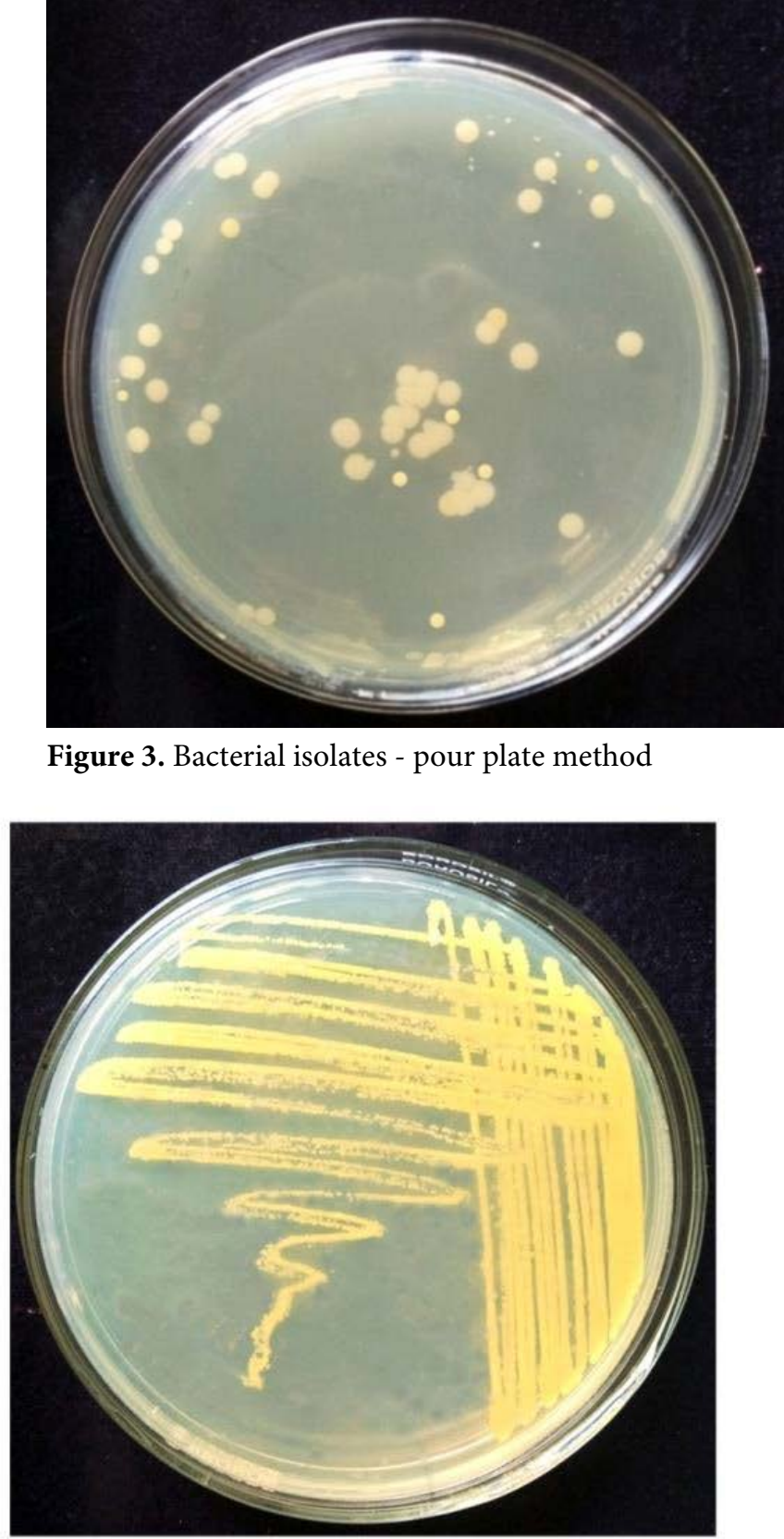

Figure 3. Bacterial isolates - pour plate method

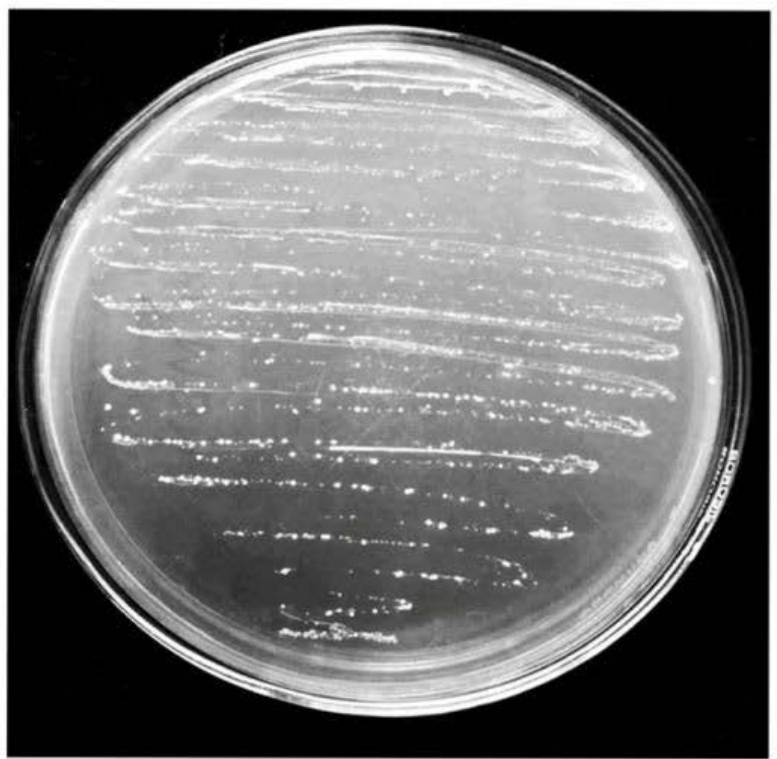

Figure 4. Pure culture of isolates from marine sponge 

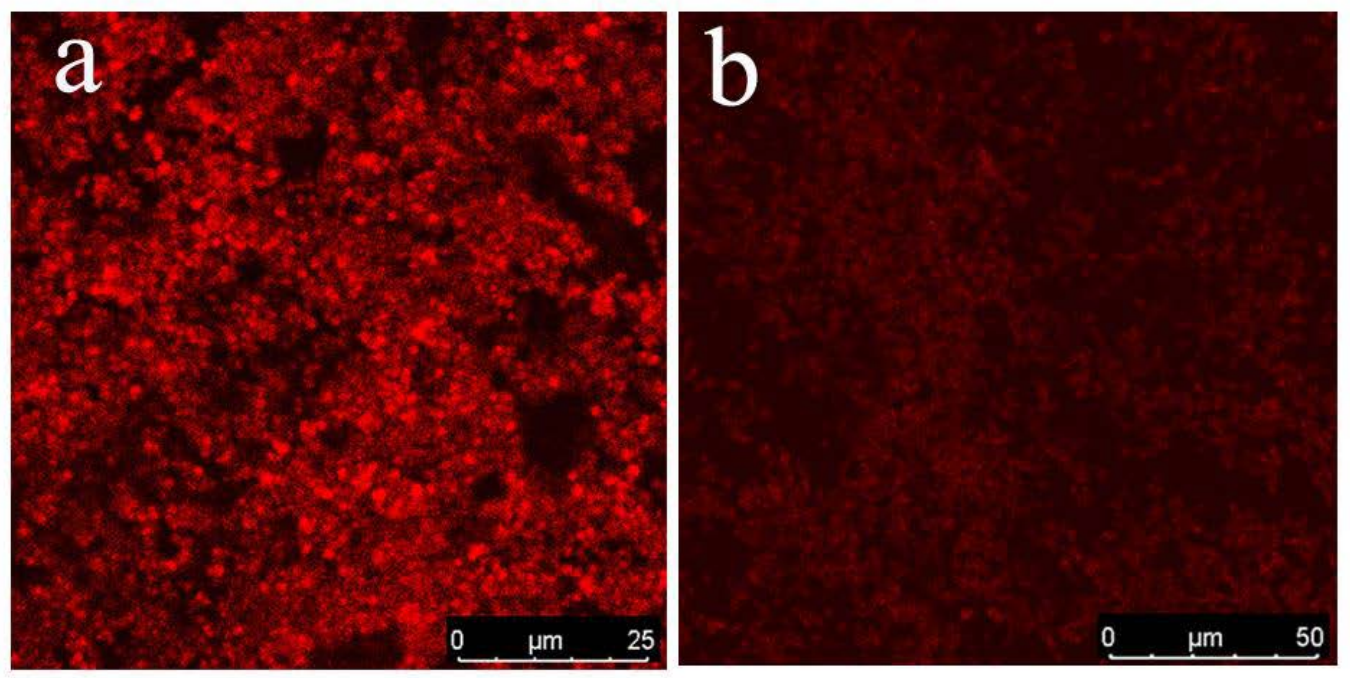

Figure 5. $\mathrm{AB} 2 \mathrm{a}$ and $\mathrm{AB} 2 \mathrm{~b}$ isolates from Callyspongia diffusa showing positive result in confocal microscopy
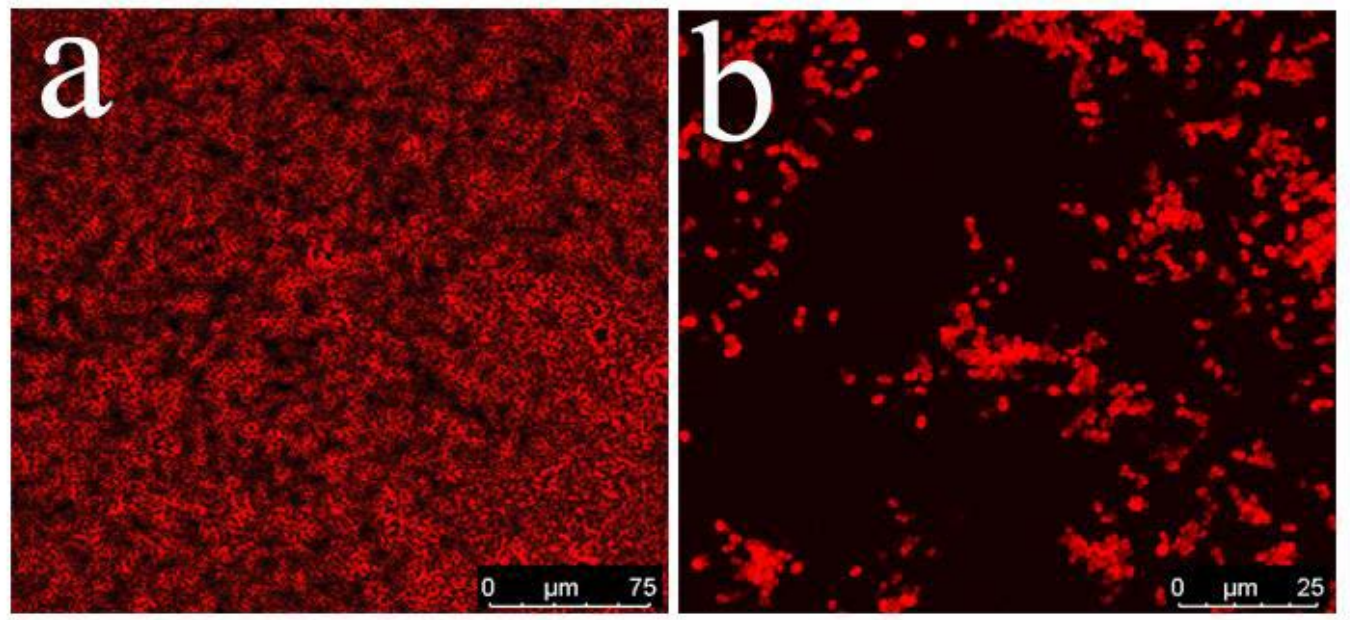

Figure 6. $\mathrm{AB} 9 \mathrm{a}$ and $\mathrm{AB} 9 \mathrm{~b}$ isolates from Mycale mytillorum showing positive result in confocal microscopy

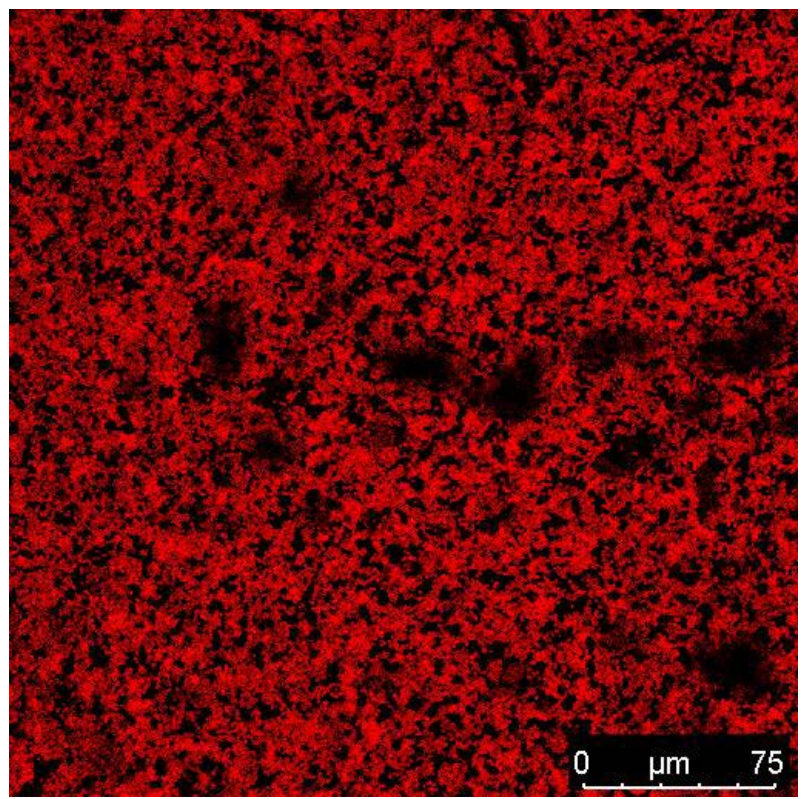

\section{Characterization of Potent PHB Isolate}

To characterize the potent isolate, Gram staining (Figure 8) and biochemical tests (Figure 9, Table 1) were performed. From that result the AB8a isolate was identified as a Gram-positive motile, sugar fermented rod-shaped Bacillus sp.

\section{Antibiotic Sensitivity Test}

Among twenty five different types of antibiotics used, AB8a was found to be resistant for Ampicillin, Cloxacillin, Cefuroxime, Bacitracin, Amoxyclav and Cephalothinand. The zone diameters of sensitivity of the organism to the antibiotics obtained were recorded (Figure 10, Table 2).

Figure 7. AB8a isolates from Oceanopia arenosa showing positive result in confocal microscopy 


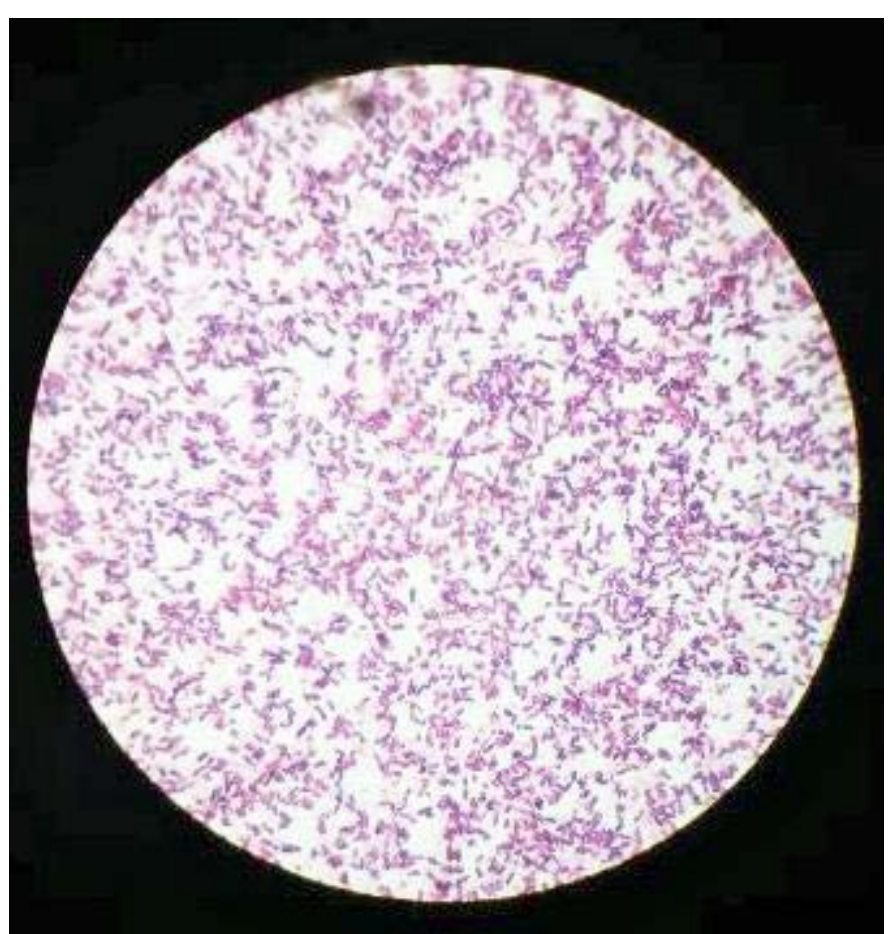

Figure 8. Gram staining of isolated bacteria

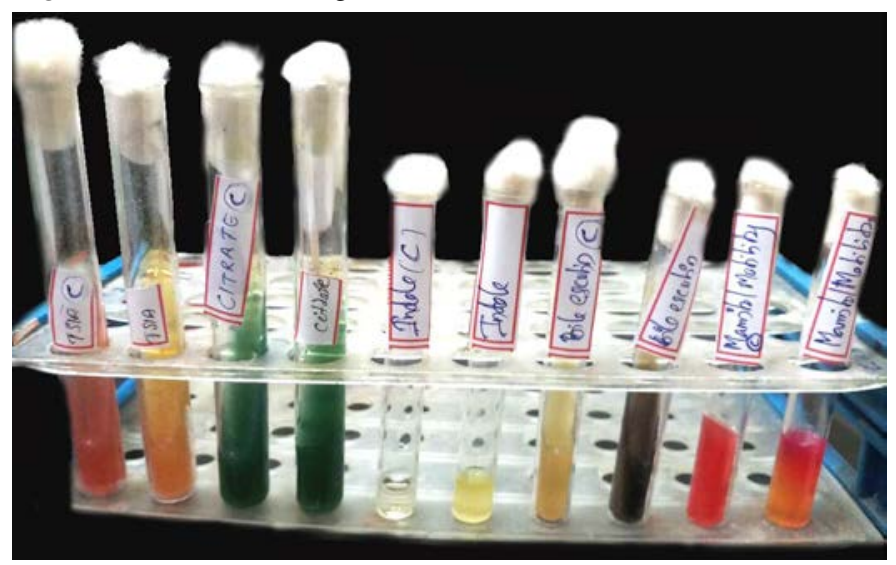

Figure 9. Biochemical tests

Table 1. Biochemical characteristics of AB8a

\begin{tabular}{ll}
\hline Test & Observation \\
\hline Motility & Motile, fermented \\
Gram stain & Gram positive \\
Catalase & + \\
Oxidase & + \\
Mannitol motility & Fermented \\
Indole & + \\
Oxidative fermentative & - \\
TSIA & Sugar fermented A/A \\
Citrate & - \\
Lysine & - \\
H2s & - \\
Urease & - \\
Shape of bacteria & Rod \\
Lactose & - \\
Glusose & + \\
Bile esculin & + \\
\hline
\end{tabular}

Table 2. List of antibiotics used along with zone diameter in $\mathrm{mm}$

\begin{tabular}{|c|c|c|c|}
\hline Antibiotics & Quantity & Code & Zone (mm) \\
\hline Ampicillin & $10 \mathrm{mcg}$ & AMP & - \\
\hline Cefotaxime & 30 & CTX & 18 \\
\hline Carbenicillin & 100 & $\mathrm{CB}$ & 15 \\
\hline Cloxacillin & 1 & COX & - \\
\hline Azithromycin & 15 & AZM & 25 \\
\hline Norfloxacin & 10 & NX & 30 \\
\hline Tobramycin & 10 & TOB & 16 \\
\hline Nalidixic acid & 30 & NA & 22 \\
\hline Cefuroxime & 30 & CXM & - \\
\hline Bacitracin & SD 105-1 CT & BT & - \\
\hline Ceftazidime & 30 & CAZ & 24 \\
\hline Amoxyclav & 30 & AMC & - \\
\hline Piperacillin & 100 & PI & 25 \\
\hline Tigecycline & 15 & TGC & 20 \\
\hline Cephalothin & 30 & $\mathrm{CZ}$ & - \\
\hline Erythromycin & 15 & $\mathrm{E}$ & 25 \\
\hline Meropenem & 10 & MRP & 33 \\
\hline Amikacin & 30 & $\mathrm{AK}$ & 20 \\
\hline Vancomycin & 30 & VA & 17 \\
\hline Gentamycin & 10 & GEN & 19 \\
\hline Ciprofloxacin & 5 & CIP & 14 \\
\hline Cotrimoxazole & 25 & COT & 20 \\
\hline Nitrofurantoin & 300 & NIT & 17 \\
\hline Pip-Tazobactam & $100 / 10$ & PIT & 19 \\
\hline Cefaperazonesulbactam & $75 / 30$ & CFS & 22 \\
\hline
\end{tabular}

Molecular Analysis for Amplification of the Genes

\section{and Phylogenetic Analysis}

Amplification and gel electrophoresis of 16S rRNA (Figure 11) showed that AB8a bacteria isolates had approximately $1500 \mathrm{bp}$ and it was belonged to bacteria groups. The phylogenic relationship of bacterial isolate (AB8a) was studied using Maximum Likelihood Method. The 16S rRNA strain sequence following pair-wise alignment exhibited $100 \%$ similarity at the DNA gene level with the members of the genus Bacillus. The ML tree was prepared (Figure 12) and clade stability was estimated using 1000 non-parametric bootstrap replications. Phylogenetic tree revealed that Bacillus flexus of the present study has got clustered with the identical reference sequence of the Bacillus flexus (MHO57386.1) from GenBank with highest boot strap value (100). The isolate of our present investigations was thus identified as B. flexus.

\section{Optimization of Cultural Parameters for PHB}

\section{Production}

Effect of different $\mathrm{pH}$ on $\mathrm{PHB}$ production indicated that, out of different $\mathrm{pH}$ of media tested, $\mathrm{pH} 7.0$ was found to be optimum for maximum $\mathrm{PHB}$ production by $B$. flexus. Effect of 
initial $\mathrm{pH}$ studies also showed that as the $\mathrm{pH}$ in the medium increases, $\mathrm{PHB}$ production increased up to $\mathrm{pH}$ 7.0. Bacillus flexus showed maximum PHB production $(2.85 \pm 0.08 \mathrm{~g} / 100 \mathrm{ml})$ at $\mathrm{pH} 7.0$, and at alkaline $\mathrm{pH}$ sharp decrease in the production of $\mathrm{PHB}$ were found. NoPHB production was observed at $\mathrm{pH} 6.0$ by the isolate. At $\mathrm{pH} 8.0$, all the isolates were found to produce lower yields showing that $\mathrm{pH} 6.0, \mathrm{pH} 8.0$ and $\mathrm{pH} 9.0$ were not suitable for $\mathrm{PHB}$ accumulation.

Effect of different incubation temperature on $\mathrm{PHB}$ accumulation was studied over a range of $20^{\circ} \mathrm{C}$ to $40^{\circ} \mathrm{C}$. The result indicated that the range of $30-35^{\circ} \mathrm{C}$ was suitable for the PHB production $(2.82 \pm 0.09 \mathrm{~g} / 100 \mathrm{ml})$. Even though $30-35^{\circ} \mathrm{C}$ range was found to be suitable for $\mathrm{PHB}$ production, $30^{\circ} \mathrm{C}$ was selected as optimum temperature for further studies. Yield and $\mathrm{PHB}$ production was low at $20^{\circ} \mathrm{C}$ and $40^{\circ} \mathrm{C}$.

Among the different carbon sources tested to evaluate their effects on PHB yield, dextrose was found to be the best carbon source. It yielded a mean PHB of $2.83 \pm 0.08 \mathrm{~g} / 100 \mathrm{ml}$. This was followed by glucose with a mean PHB of $1.55 \pm 0.10 \mathrm{~g} / 100 \mathrm{ml}$.
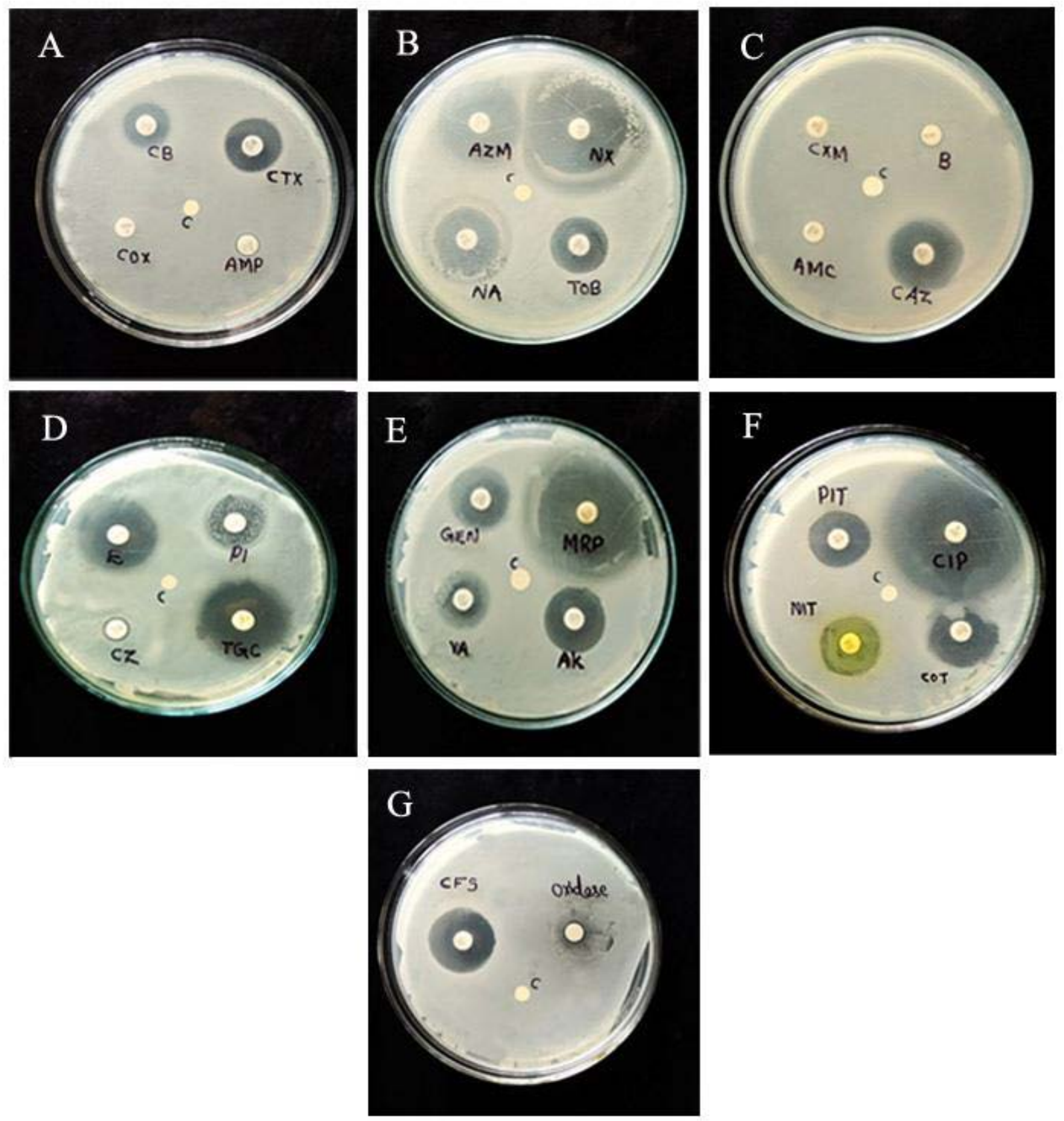

Figure 10. Antibiotic sensitivity test of the isolate; A: CB- carbenicillin; CTX-Cefotaxime; COX-Cloxacillin; AMP- Ampicillin; B: AZMAzithromycin; NX-Norfloxacin; NA-Nalidixic acid; TOB-Tobramycin; C: CXM- Cefuroxime; BT-Bacitracin; AMC-Amoxyclav; CAZ Ceftazidime; D: E- Erythromycin; CZ-Cephalothin; PI-Piperacillin; TGC-Tigecycline; E: GEN- Gentamicin; MRP-Meropenem; VAVancomycin; AK-Amikacin; F: PIT- Pip-Tazobactam; NIT-Nitrofurantoin; COT-Cotrimoxazole; CIP-Ciprofloxacin; G: CFSCefaperazone sulbactam 


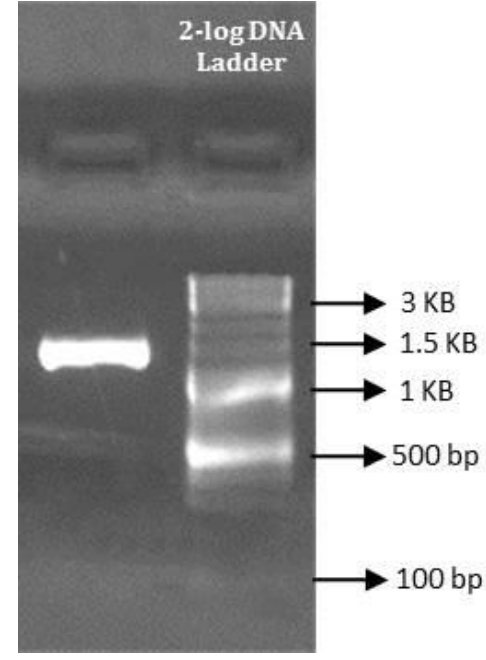

Figure 11. Details of partial $16 \mathrm{~S}$ ribosomal RNA of AB8a bacteria isolates

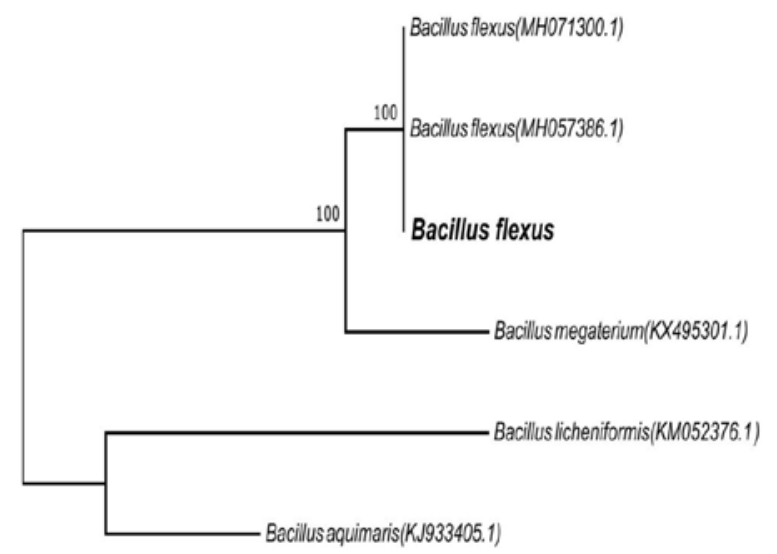

$\longmapsto_{0.0050}$

Figure 12. Phylogenetic tree of isolate Bacillus flexus and their closest NCBI (BLASTn) strains based on the 16S rRNA gene sequences

\section{Extraction and Characterization of PHB}

The sodium hypochlorite method was selected for the extraction of $\mathrm{PHB}$. The precipitate was allowed to evaporate to obtain PHB crystals (Figure 13).

\section{Fourier Transform Infrared Spectroscopy (FTIR)}

The IR spectrum of each sample represents its total chemical composition, because every chemical compound in the sample makes its own specific contribution to the absorbance spectrum. The FTIR Spectra (Figure 17) were recorded at $4000 \mathrm{~cm}^{-1}$ to $400 \mathrm{~cm}^{-1}$ range. From the spectrum obtained it was inferred that the band at $3457 \mathrm{~cm}^{-1}$ corresponds to $\mathrm{OH}$ (Hydroxyl) group, whereas band at $1692 \mathrm{~cm}^{-1}$ represents $\mathrm{C}=\mathrm{O}$ (Carbonyl) and COO (ester) groups. The band at $1454 \mathrm{~cm}^{-1}$ corresponds to $\mathrm{CH}$ showing asymmetrical stretching and the band at $1550 \mathrm{~cm}^{-1}$ indicating bending vibration in $\mathrm{CH} 3$ group, whereas band at $1420 \mathrm{~cm}^{-1}$ representing $\mathrm{CH} 2$ bond. Stretch of bands ranging from $1050-1190 \mathrm{~cm}^{-1}$ showed C-O bonding.

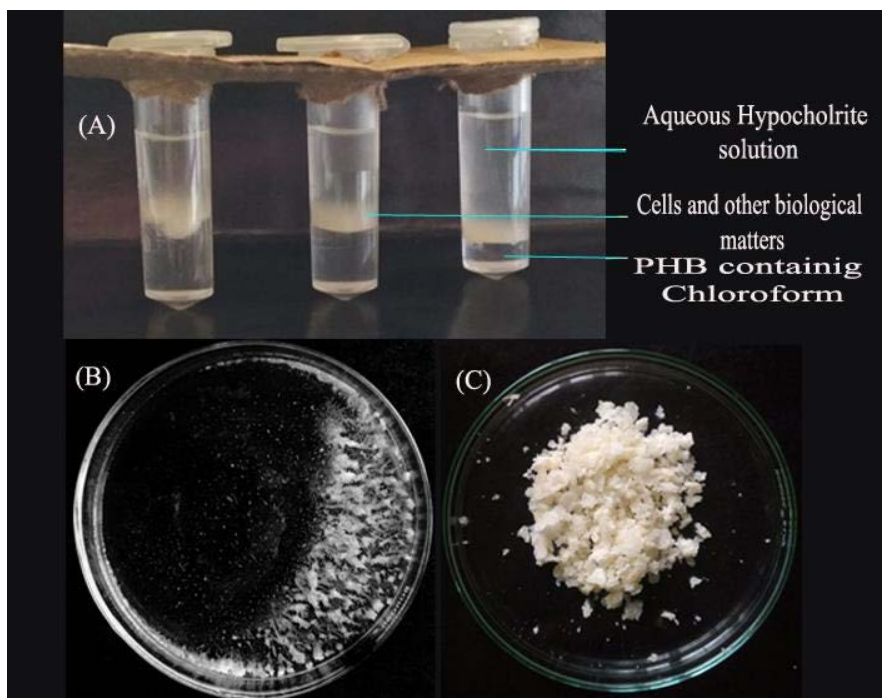

Figure 13. (A) Three different phase appeared after centrifugation, (B) PHB crystals obtained after the evaporation of chloroform by Sodium - Chloroform method, (C) Extracted PHB crystals

\section{Nuclear Magnetic Resonance (NMR) Spectroscopy}

The NMR spectrum (Figure 18) showed a triplet at $1.3 \mathrm{ppm}$ which is attributed to the methyl group $\left(-\mathrm{CH}_{3}\right)$ coupled to one proton. Doublet peak ranging between 2.06-2.6862 is attributed to the methylene group $\left(-\mathrm{CH}_{2}\right)$ adjacent to an asymmetric carbon atom bearing a single atom. The multiple peak at 4.88 $\mathrm{ppm}$ is characteristic of methine group $(-\mathrm{CH})$. Two other signals are observed, a broad one at $3.88 \mathrm{ppm}$ which is due to water and another at 7.93 and $8.599 \mathrm{ppm}$ is may attributed to the solvent used i.e. methanol.

\section{Discussion}

The marine environment provides a real untapped resource for novel bacteria and possibly the biopolymers they produce and this study was aimed to isolate a diverse range of $\mathrm{PHB}$ accumulating bacteria from marine sponges and the parameters for maximum PHB production were also optimized (Arun et al., 2009; Madison \& Huisman, 1999). Based on morphological features and nature of spicules the collected marine sponges specimens were identified as Callyspongia (Cladochalina) fibrosa (Ridley \& Dendy, 1886), Callyspongia (Cladochalina) diffusa (Ridley, 1884), Tedania (Tedania) anhelans (Vio in Olivi, 1792), Myxilla (Ectyomyxilla) arenaria (Dendy, 1905), 


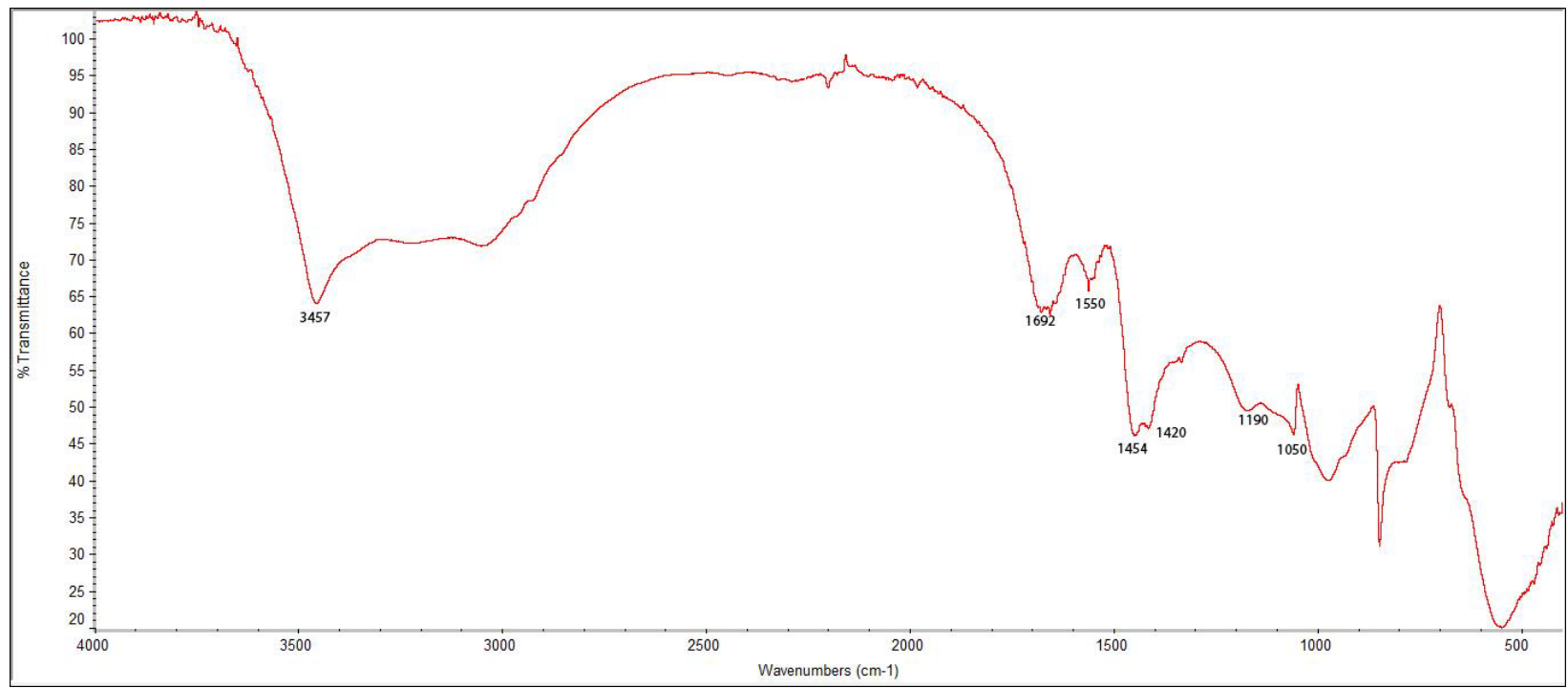

Figure 14. FT-IR spectrum of extracted PHB

PHB PLYMER H1 MeOD

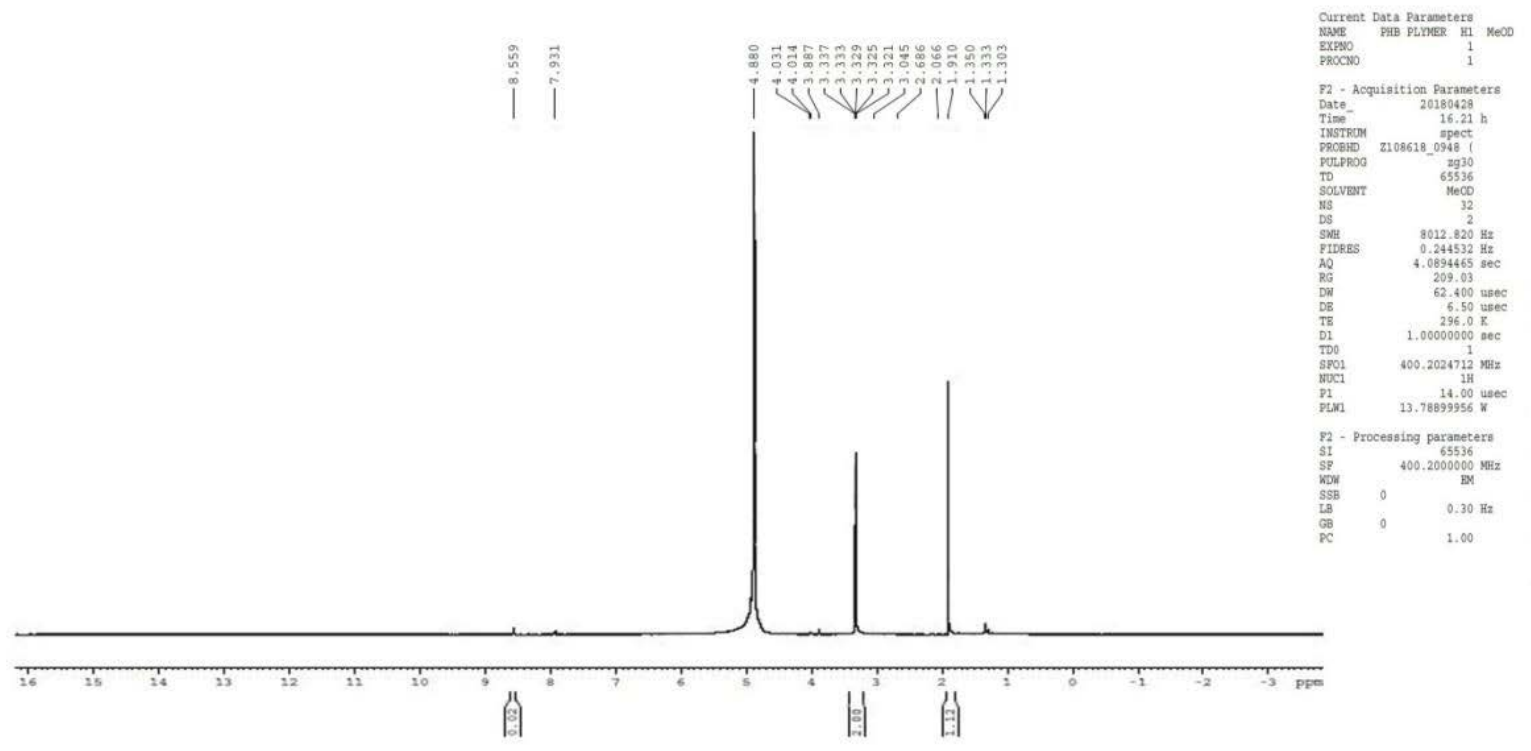

Figure 15. ${ }^{1} \mathrm{H}$ NMR spectrum of extracted $\mathrm{PHB}$

Sigmadocia carnosa (Dendy, 1889), Dysidea fragilis (Montagu, 1814), Ecionemia acervus (Bowerbank, 1864), Oceanopia arenosa (Rao, 1941), Mycale (Carmia) mytilorum (Annandale, 1914) and Mycale (Aegogropila) crassissima (Dendy, 1905). Many reports reveals that these types of marine sponges are very common in Indian coastal areas including Tuticorin coast (Singla et al., 2013), Lakshadweep archipelago, Kavaratti Island (Gopi et al., 2012) and Gulf of Mannar and Mandapam bay (Velho-Pereira \& Furtado, 2012). Selvakumar and Dhevendaran (2016) reported the occurrence of Callyspongia diffusa, Mycale mytilorum, Tedania anhelans and Dysidea fragilis from South West coast of India.

The result of the work indicated that five bacterial strains afforded fluorescence signals with Nile-blue test. Moreover, one of them (AB8a) gave a very strong fluorescence signal, whereas the other strains showed faint signals. In addition, the high fluoresced strain was predicted as one of the effective producer of $\mathrm{PHB}$ based on the growth rate, the high intensity of fluorescence in viable Nile blue A staining and the presence of lipophilic inclusions. Spiekermann et al. (1999) reported that the Nile-blue stain emitted strongly positive fluorescence signals only with a hydrophobic compound like PHAs and lipids and could be detected by fluorescence spectroscopy or flow cytometry.

Microbiological properties were investigated according to the methods described in Bergey's Manual of Systematic Bacteriology (Kreig \& Holt, 1984) and the organism was identified as a member of the genus, Bacillus. The Grampositive bacteria, such as Bacillus sp. could be considered as ideal candidates for the industrial $\mathrm{PHB}$ production due to the 
lack of LPS layer. Bacillus sp. has pronounced importance in industry due to their advantages of low nutritional requirements, rapid growth, having machinery enzymes and for utilization of several sugars (El-Sheekh, 2015). Members of this genus are known to grow rapidly, possess various hydrolytic enzymes and produce copolymers from structurally unrelated carbon sources (Halami, 2007; Valappil et al., 2007) and accordingly these characteristics of Bacillus sp. can be considered for the production of PHB with desirable material properties from various low-cost agricultural feed stocks.

Further characterization was confirmed with 16S rRNA sequence. The phylogenic relationship of bacterial isolate (AB8a) was studied using Maximum Likelihood Method. The $16 \mathrm{~S}$ rRNA strain sequence following pair-wise alignment exhibited $100 \%$ similarity at the DNA gene level with the members of the genus Bacillus. Phylogenetic tree revealed that Bacillus flexus of the present study has got clustered with the identical reference sequence of the Bacillus flexus (MHO57386.1) from GenBank with highest boot strap value (100). The isolate of our present investigations was thus identified as B. flexus. In prokaryotes PHB accumulation property is broadly distributed among the Gram-negative organisms such as Cupriavidus, Pseudomonas, etc., and Grampositive organisms such as Bacillus, Clostridium, Corynebacterium, Nocardia, Rhodococcus, Streptomyces, Staphylococcus etc. and certain archaeal strains of Halobacterium, Haloarcula, Haloquadratum and Haloferax. Bacillus spp. are well known for their ability to accumulate poly-3-hydroxybutyrate (PHB) (Balakrishna Pillai et al., 2017). According to Beveridge (2001) marine environment have reported that around $36 \%$ of the symbiotic isolates are Gramnegative rods. In our study, a Gram positive Bacillus was isolated from Oceanopia arenosa. Generally, bacteria belonging to the genera Bacillus accumulate short chain length polyhydroxyalkanoates such as PHB (Valappil et al., 2007).

Effect of incubation temperature on yield and $\mathrm{PHB}$ accumulation was studied over a range of temperature $20^{\circ} \mathrm{C}$ to $40^{\circ} \mathrm{C}$. The result indicated the range of $30-35^{\circ} \mathrm{C}$ was suitable for the biomass and PHB production $(73.40 \%$ yield). The incubation temperature ranging from 27 to $30^{\circ} \mathrm{C}$ favored $\mathrm{PHB}$ production and the maximal yield was attained at $30^{\circ} \mathrm{C}$. The most adverse effect of incubation temperature on both $\mathrm{PHB}$ was recorded above $30^{\circ} \mathrm{C}$. This result accorded to a great extent with those obtained by Divyashree et al. (2009a, b), who grew B. flexus strain at $30^{\circ} \mathrm{C}$ for PHA production. Higher or lower temperatures showed inferior results. This result also coincides with that represented by Aslim et al. (2002), who reported that optimum incubation temperature for $\mathrm{PHB}$ production by Bacillus thuringiensis, Bacillus subtilis, and Bacillus pumilis was at $35^{\circ} \mathrm{C}$. According to Tamodgan \& Sidal (2011) higher and lower temperatures than $30^{\circ} \mathrm{C}$ lead to decrease in PHB synthesis by Bacillus subtilis ATCC 6633, as well as cell mass, probably due to the low enzymes activity. In this study, the optimum temperature for $\mathrm{PHB}$ production was found to be in $30^{\circ} \mathrm{C}$. These results are similar with Grothe et al. (1999) that incubation temperature affects polymer accumulation at a range of $30-35^{\circ} \mathrm{C}$ and over this range, the effect of temperature is negligible. Interestingly, our isolated strain $\mathrm{AB} 8 \mathrm{a}$ could accumulate the highest amount of $\mathrm{PHB}$ within $36 \mathrm{hrs}$ that is very short time compared to previously reported Bacillus strains. Maximum PHB production from molasses was obtained after $72 \mathrm{hrs}$ by Bacillus flexus ME-77 (El-Sheekh, 2015) and Bacillus thuringiensis (Desouky et al., 2014). Kalaivani \& Sukumaran (2015) also reported maximum production of PHB from molasses observed after 76 hrs by Bacillus sp. KSN5.

Dextrose among all the other carbon sources led to the highest PHB production (70.25\%) compared to glucose and mannitol. In addition, the enhancing effect of dextrose is probably due to its additional nutrients, such as trace elements, minerals and vitamins as thiamine and riboflavin (Oliveira et al., 2004). Gouda et al. (2001) studied the effect of different carbon sources on the production of PHB using Bacillus megaterium. In that study maximum $\mathrm{PHB}$ production was obtained from glucose and maximum cell dry mass was obtained from maltose. In this study among the carbon compounds used, dextrose was found to be best for PHB accumulation and mannitol was found to be poor carbon source.

It has been reported that $\mathrm{pH}$ in the range of 6.0-7.5 was the best for microbial growth and $\mathrm{PHB}$ production of Alcaligenes eutrophus was reported at optimum $\mathrm{pH}$ of 6.9, and the growth declined at $\mathrm{pH}$ below 5.4 (Grothe et al., 1999). Even a slight change in $\mathrm{pH}$ will cause malfunctioning of metabolic processes (Wei et al., 2011), and drastic changes in PHB production seems to be due to the effect of initial $\mathrm{pH}$ on the bioavailability of trace elements (Ramadas et al., 2009). In the present study, maximum $\mathrm{PHB}$ production obtained at $\mathrm{pH} 7.0$ (73.55\%). Flora et al. (2010) revealed that the maximum PHB production (25\%) by Bacillus sphaerius was at $\mathrm{pH}$ range from 6.5-7.5. Earlier reports of Sivaprakasam et al. (2008) concluded that the optimum $\mathrm{pH}$ for growth of $\mathrm{B}$. flexus was 8.0, while Priest et al. (1988) revealed that $\mathrm{B}$. flexus can tolerate $\mathrm{pH}$ range from 4.5 to 9.5 .

The biopolymer was extracted from the bacterial pellet using dispersion of sodium hypochlorite and chloroform solution. The extracted $\mathrm{PHB}$ was characterized by FTIR and $1 \mathrm{H}$ NMR for the confirmation as PHB. The PHB sample extracted 
was analyzed qualitatively by FTIR Spectrophotometer to know the presence of different functional groups. In the present study, the FTIR spectrum of the PHB sample shows major peaks at 3457,1692,1550,1454,1420, 1190 and $1050 \mathrm{~cm}^{-1}$, whereas the remaining peaks are closely lying between $3450 \mathrm{~cm}^{-1}$ and $600 \mathrm{~cm}^{-1}$.The IR spectrum reflects both monomeric units in addition a strong absorption band at $1714 \mathrm{~cm}^{-1}$ was detected in G1S1 (Bacillus subtilis), as is expected for the $\mathrm{C}=\mathrm{O}$ (Shah, 2014). All absorptions due to the PHB moiety appeared in the spectrum, and in addition a strong absorption band at $1639 \mathrm{~cm}^{-1}$ was detected a thioester bond (Shah, 2012). As an evidence of this finding, the work done by Rohini et al. (2006) can be equated. They identified the polymer with the spectrum which revealed the presence of three groups of signals characteristic of PHB by the doublet at $1.3 \mathrm{ppm}$ attributed to the methyl group coupled to one proton and the spectrum of the quadruplet at $2.57 \mathrm{ppm}$ the methylene group adjacent to the asymmetric carbon atom having single proton and the multiplet at $5.28 \mathrm{ppm}$ to the methylene group.

The results of this study demonstrates that the bacterium, which is isolated from marine sponge Oceanopia arenosa, identified as Bacillus flexus could be an effective and interesting bacterial sp., for production of PHB from dextrose. However, Use of inexpensive substrates could contribute to reducing the $\mathrm{PHB}$ production cost and further studies are needed for large scale production of the PHB.

\section{Conclusion}

The present investigation provides basis for assessing a potential for using sponge symbiotic bacteria for $\mathrm{PHB}$ (a biodegradable plastic) production, which is an economically and environmentally important product. In this study, sixteen marine bacterial strains associated with ten species of sponges Callyspongia (Cladochalina) fibrosa, Callyspongia (Cladochalina) diffusa (Ridley, 1884), Tedania (Tedania) anhalens (Vio in Olivi, 1792), Myxilla arenaria (Dendy, 1905), Sigmadocia carnosa (Dendy, 1889), Dysidea fragilis (Montagu, 1814), Ecionemia acervus (Bowerbank, 1864), Oceanopia arenosa Rao, (1941), Mycale mytilorum Annandale and Mycale crassissima were isolated. Ten isolates showed growth in Minimal Davis Media were further stained with Nile blue staining and observed under Leica LSCM - Laser Spectral Scanning Confocal Microscope to confirm the production of $\mathrm{PHB}$. Five isolates such as two strains each from Callyspongia diffusa (AB2a, AB2b), Mycale mytillorum (AB9a, AB9b) and one isolate from Oceanopia arenosa Rao (AB8a) flourish bright yellowish-orange color were assumed as the $\mathrm{PHB}$ producing colonies. Yellow pigmented AB8a isolate from Oceanopia arenosa showed high intensity was selected for further observations and study. In addition, AB8a was subjected to morphological, biochemical and phylogenetic characterization. The results of the tests showed AB8a to be a Gram-positive, sporulating, motile, catalase,oxidase positive and rod shaped bacteria. The highest PHB production $(70.25 \% / 100 \mathrm{~mL})$ was achieved at $\mathrm{pH} 7.0$ by applying dextrose as medium at incubation temperature $30^{\circ} \mathrm{C}$ and $150 \mathrm{rpm}$ agitation speed. The biopolymer was extracted from the bacterial pellet using dispersion of sodium hypochlorite and chloroform solution. The extracted PHB was characterized by FT-IR and $1 \mathrm{H}$ NMR for the confirmation as PHB. Phylogenetic analysis based on comparative analysis of sequenced 16s rRNA of the active strains indicated a preponderance of bacteria belonging to Bacillus flexus with $100 \%$ sequence similarities.

\section{Acknowledgements}

The authors are grateful to Dr. A. Biju Kumar, Professor and Head, Department of Aquatic Biology and Fisheries, University of Kerala for providing lab facilities. We are thankful to Dr. P. A. Thomas, Principal Scientist (Retired), C. M. F. R. I. and Mr. K. S. Arun for their support in the identification of sponges. We thank Mr. S. A. Syam, Mr. Julekh and Mr. Jibin, Technical staffs of Central Laboratory for Instrumentation and Facilitation (CLIF) for the confocal imaging, FT-IR and NMR analysis, Mr. A. Riyas for his assistance in phylogenetic studies, and $\mathrm{Mr}$. $\mathrm{H}$. Alsif, Department of Biochemistry and Industrial Microbiology, National College of Arts and Science for his technical support.

\section{Compliance with Ethical Standards}

\section{Authors' Contributions}

DA and VSP conceived and designed the study, collect specimens, analyze the data and wrote the manuscript. DA carried out the experimental work, interpret the data, reviewed the results. VSP guided the research work, performed editing, critical revision and supervised the findings of the study. Both authors read and approved the final manuscript.

\section{Conflict of Interest}

The authors declare that they have no conflict of interest.

\section{Ethical Approval}

For this type of study, formal consent is not required. 


\section{References}

Annandale, N. (1914). Fauna symbiotica indica. 5. Some sponges commonly associated with oysters and mussels in Madras Harbour and the Chilka Lake. Records of the Indian Museum, 10: 149-158. https://doi.org/10.5962/bhl.part.5625

Arun, A., Arthi, R., Shanmugabalaji, V. \& Eyini, M. (2009). Microbial production of poly-beta-hydroxybutyrate by marine microbes isolated from various marine environments. Bioresource Technology, 100(7): 23202323. https://doi.org/10.1016/j.biortech.2008.08.037

Aslim, B., Yuksekdag, Z. \& Beyatli, Y. (2002). Determination of PHB Growth Quantities of Certain Bacillus Species Isolated From Soil. Turkish Electronic Journal of Biotechnology, Special Issue, 24-30.

Balakrishna Pillai, A., Jaya Kumar, A., Thulasi, K. \& Kumarapilla, H. (2017). Evaluation of short-chainlength polyhydroxyalkanoate accumulation in Bacillus aryabhattai. Brazilian Journal of Microbiology, 48(3): 451-460. https://doi.org/10.1016/j.bjm.2017.01.005

Bauer, A. W., Kirby, W. M. M. \& Turck, M. (1966). Antibiotic Susceptibility Testing by a Standardized Single Disk Method. American Journal of Clinical Pathology, 45(4_ts): 493-496.

https://doi.org/10.1093/AJCP/45.4 TS.493

Baumann, P., Baumann, L., Mandel, M. \& Allen, R. D. (1971). Taxonomy of marine bacteria: Beneckea nigrapulchrituda sp. n. Journal of Bacteriology, 108(3): 1380-1383. $\quad$ https://doi.org/10.1128/JB.108.3.1380$\underline{1383.1971}$

Beveridge, T. J. (2001).Use of the Gram stain in microbiology. Biotechnic \& Histochemistry, 76(3): 111-118. https://doi.org/10.1080/bih.76.3.111.118

Bhuwal, A. K., Singh, G., Aggarwal, N. K., Goyal, V. \& Yadav, A. (2014). Poly- $\beta$-hydroxybutyrate production and management of cardboard industry effluent by new Bacillus sp. NA10. Bioresources and Bioprocessing, 1(1): 9. https://doi.org/10.1186/s40643-014-0009-5

Bowerbank, J. S. (1864). A monograph of the British Spongidae, Vol 1. London: The Ray Society.

Castilho, L. R., Mitchell, D. A. \& Freire, D. M. G. (2009). Production of polyhydroxyalkanoates (PHAs) from waste materials and by-products by submerged and solid-state fermentation. Bioresource Technology, 100(23): 5996-6009.
Chen, G. Q. (2009). A microbial polyhydroxyalkanoates (PHA) based bio and materials industry. Chemical Society Reviews, $\quad 38(8)$ :

2434-2446. https://doi.org/10.1039/B812677C

Dendy, A. (1889). Report on a second collection of sponges from the Gulf of Manaar. Annals and Magazine of Natural History, 3(6): $\quad$ 73-99. https://doi.org/10.1080/00222938909460303

Dendy, A. (1905). Report on the sponges collected by Professor Herdman, at Ceylon, in 1902 (pp. 57-246). In: Herdman, W.A. (Ed.), Report to the Government of Ceylon on the Pearl Oyster Fisheries of the Gulf of Manaar. 3 (Supplement 18). (Royal Society: London).

Divyashree, M. S., Rastogi, N. K. \& Shamala, T. R. (2009b). A simple kinetic model for growth and biosynthesis of polyhydroxyalkanoate in Bacillus flexus. New Biotechnology, 26(1-2): 92-98. https://doi.org/10.1016/j.nbt.2009.04.004

Divyashree, M. S., Shamala, T. R. \& Rastogi, N. K. (2009a). Isolation of polyhydroxyalkanoate from hydrolyzed cells of Bacillus flexus using aqueous two-phase system containing polyethylene glycol and phosphate. Biotechnology and Bioprocess Engineering, 14: 482-489. https://doi.org/10.1007/s12257-008-0119-z

El-Sheekh, M. M., El-Abd, M. A. \& El-Diwany, A. I. (2015). Poly-3 hydroxybutyrate production by Bacillus flexus ME-77 using some industrial wastes. Rendiconti Lincei, 26(2): 109-119. https://doi.org/10.1007/s12210-0140368-Z

Enkicknap, J. J., Kelly, M., Peraud, O. \& Hill, R. T. (2006) Characterization of a culturable alphaproteobacterial symbiont common to many marine sponges and evidence for vertical transmission via sponge larvae. Applied and Environmental Microbiology, 72(5): 37243732. https://doi.org/10.1128/aem.72.5.3724-3732.2006

Flora, G., Bhatt, K. \& Tuteja, U. (2010). Optimization of culture conditions for poly A-Hydroxybutyrate production from isolated Bacillus species. Journal of Cell and Tissue Research, 10(2): 2235-2242.

Gandhimathi, R., Arunkumar, M., Selvin, J., Thangavelu, T., Sivaramakrishnan, S., Kiran, G. S., Shanmughapriya, S. \& Natarajaseenivasan, K. (2008). Antimicrobial potential of sponge associated marine actinomycetes. Journal of Medical Mycology, 18(1): 16-22. https://doi.org/10.1016/j.mycmed.2007.11.001

https://doi.org/10.1016/j.biortech.2009.03.088 
Getachew, A. \& Woldesenbet, F. (2016). Production of biodegradable plastic by polyhydroxybutyrate (PHB) accumulating bacteria using low cost agricultural waste material. BMC Research Notes, 9: 509. https://doi.org/10.1186/s13104-016-2321-y

Gopi, M., Kumaran, S., Kumar, T. T., Deivasigamani, B., Alagappan, K. \& Prasad, S. G. (2012). Antibacterial potential of sponge endosymbiont marine Enterobacter sp. at Kavaratti Island, Lakshadweep archipelago. Asian Pacific Journal of Tropical Medicine, 5(2): 142-146. https://doi.org/10.1016/S1995-7645(12)60013-3

Gouda, M. K., Swellam, A. E. \& Omar, S. H. (2001).Production of PHB by a Bacillus megaterium strain using sugarcane molasses and corn steep liquor as sole carbon \& nitrogen sources. Microbiological Research, 156(3): 201-207. https://doi.org/10.1078/0944-5013-00104

Grothe, E., Moo-Young, M. \& Chisti, Y. (1999). Fermentation optimization for the production of poly-(Bhydroxybutyric acid) microbial thermoplastic. Enzyme and Microbial Technology, 25(1): 132-141.

Halami, P. (2007). Production of polyhydroxyalkanoate from starch by the native isolate Bacillus cereus CFR06. World Journal of Microbiology and Biotechnology, 24: 805-812. https://doi.org/10.1007/s11274-007-9543-Z

Hall, T. A. (1999). BioEdit A User-Friendly Biological Sequence Alignment Editor \& Analysis Program for Windows 95/98/NT. Nucleic Acids Symposium Series, 41: 95-98.

Hooper, J. N. A. \& Van Soest, R., W., M. (2002). Systema Porifera: A guide to the classification of sponges. Kluwer Academic/Plenum Publishers, New York, USA. 1-1099.

Hooper, J. N. A. (2003). Sponguide. Guide to sponge collection \& identification. Queensl and Museum, Australia., 1-26. https://doi.org/10.1128/AEM.72.3.2118-2125.2006

Kalaivani, R. \& Sukumaran, V. (2015). Enhancement of technique for optimized production of PHA from marine bacteria, utilizing cheaply available carbon sources at Thanjavur district, India. International Journal of Current Microbiology and Applied Sciences, 4(4): 408-417.

Kansiz, M., Jacobe, H. B. \& McNaughton, D. (2000). Quantitative Determination of the Biodegradable Polymer Poly ( $\beta$-hydroxybutyrate) in a Recombinant Escherichia coli Strain by Use of Mid-Infrared Spectroscopy and Multivariative Statistics. Applied and Environmental Microbiology, 66(8): 3415-3420. https://doi.org/10.1128/AEM.66.8.3415-3420.2000
Kim, T. K., Hewavitharana, A. K., Shaw P. N. \& Fuerst J. A. (2006). Discovery of a new source of rifamycin antibiotic in marine sponge actinobacteria by phylogenetic prediction. Applied and Environmental Microbiology, 72(3): 2118-2125.

Kirk, R. G \& Ginzburg, M. (1972). Ultrastructure of two species of halobacterium. Journal of Ultrastructure Research, 41(1-2): $\quad$ 80-94. $\quad$ https://doi.org/10.1016/S00225320(72)90040-8

Koller, M. (2018). Biodegradable and Biocompatible Polyhydroxy-alkanoates (PHA): Auspicious Microbial Macromolecules for Pharmaceutical and Therapeutic Applications. $\quad$ Molecules, $23(2)$ : 362. https://doi.org/10.3390/molecules23020362

Koopmans, M., Rijswijk, P. V., Martens, D., EgovoraZachernyuk, T. A. Middelburg, J. J. \& Wijffels, R. H. (2011). Carbon conversion and metabolic rates in two marine sponges. Marine Biology, 158: 9-20. https://doi.org/10.1007/s00227-010-1538-x

Kreig, N. \& Holt, J. (1984). Bergey's manual of systematic Bacteriology. Williams and Wilkins, Baltimore.

Lie, J. \& Zhou, J. (2002). A marine natural product database. Journal of Chemical Information and Computer Sciences, 42(3): 742-744. https://doi.org/10.1021/ci010111x

Lillie, R. D. (1977). H.J. Conn's biological stains: A handbook on the nature and uses of the dyes employed in the biological laboratory. (9th ed.). The Williams and Wilkins Co., Baltimore.

Madison, L. \& Huisman, G. (1999). Metabolic engineering of poly (3-hydroxyalkanoates): from DNA to plastic. Microbiology and Molecular Biology Reviews, 63(1): 2153.

Montagu, G. (1814). An essay on sponges, with descriptions of all the species that have been discovered on the coast of Great Britain. Memoirs of the Wernerian Natural History Society, 2(1): 67-122.

Numata, K. \& Morisaki, K. (2015). Screening of marine bacteria to synthesize polyhydroxyalkanoate from lignin: contribution of lignin derivatives to biosynthesis by Oceanimonas doudoroffii. ACS Sustainable Chemistry \& Engineering, 3(4): 569-573. https://doi.org/10.1021/acssuschemeng.5b00031

Oliveira, F., Freire, D. \& Castilho, L. (2004). Production of poly (3-hydroxybutyrate) by solid-state fermentation with Ralstonia eutropha. Biotechnology Letters, 26: 18511855. https://doi.org/10.1007/s10529-004-5315-0 
Oliver, J. D. \& Colwell, R. R. (1973). Extractable lipids of gramnegative marine bacteria: phospholipid composition. Journal of Bacteriology, 114(3): 897-908. https://doi.org/10.1128/JB.114.3.897-908.1973

Ostle, A. G. \& Holt, J. G. (1982). Nile blue A as a fluorescent stain for poly-3-hydroxybutyrate. Applied and Environmental Microbiology, 44(1): 238-241. https://doi.org/10.1128/aem.44.1.238-241.1982

Poli, A., Di Donato, P., Abbamondi, G. R. \& Nicolaus, B. (2011). Synthesis, production, and biotechnological applications of exopolysaccharides and polyhydroxyalkanoates by Archaea. Archaea, 2011: 693253. https://doi.org/10.1155/2011/693253

Poli, A., Finore, I., Romano, I., Gioiello, A., Lama, L. \& Nicolaus, B. (2017). Microbial diversity in extreme marine habitats and their biomolecules. Microorganisms, $\quad \mathbf{5 ( 2 ) :} 25$. https://doi.org/10.3390/microorganisms5020025

Rachanamol, R. S., Lipton, A. P., Thankamani, V., Sarika, A. R. \& Selvin, J. (2014). Molecular characterization and bioactivity profile of the tropical sponge associated with bacterium Shewanella algae VCDB. Helgoland Marine Research, 68: 263-269. https://doi.org/10.1007/s10152014-0386-3

Ramadas, N., Singh, S., Soccol, C. \& Pandev, A. (2009). Polyhydroxybutyrate production using agro-industrial residue as substrate by Bacillus sphaericus NCIM 5149. Brazilian Archives of Biology and Technology, 52(1): 1723. https://doi.org/10.1590/S1516-89132009000100003

Rao, H. S. (1941). Indian and Ceylon sponges of the Naturhistoriska Riksmuseet, Stockholm, collected by K. Fristedt. Rec. Indian Museum, 43: 417-469.

Rehm, B. H. A. (2010). Bacterial polymers: biosynthesis, modifications and applications. Nature Reviews Microbiology, $\quad$ 8: $578-92$. https://doi.org/10.1038/nrmicro2354

Ridley, S. O. \& Dendy, A. (1886). Preliminary report on the Monaxonida collected by H.M.S. Challenger. Part I. Annals \& Magazine of Natural History, 18: 325-351, 470-493.

Ridley, S. O. (1884). Spongiida. In: Report on the Zoological Collections made in the Indo-Pacific Ocean during the Voyage of H.M.S. 'Alert', 1881-2. (British Museum (Natural History): London). 366-482, 582-630.

Rohini, D., Phadni, S. \& Rawal, S. K. (2006). Synthesis \& characterization of poly beta hydroxybutyrate from Bacillus thuringiensis. Indian Journal of Biotechnology, 5: 276-283.
S. E., El-Shiek, H. H., Elabd, M. A. \& Shehab, A. M. (2014). Screening, optimization and extraction of polyhydroxyalkanoates from Bacillus thuringienesis. Journal of Advances in Biology \& Biotechnology, 1(1): 4054. https://doi.org/10.9734/JABB/2014/12286

Saharan, B. S., Grewal, A. \& Kumar, P. (2014). Biotechnological Production of Polyhydroxyalkanoates: A review on trends and latest developments. Chinese Journal of Biology, 2014: 802984. https://doi.org/10.1155/2014/802984

Selvakumar, D. \& Dhevendaran, K. (2016). Antagonistic activity of marine sponges associated Actinobacteria. Journal of Coastal Life Medicine, 4(6): 465-474. https://doi.org/10.12980/JCLM.4.2016J6-17

Selvin, J., Thangavelu, T., Kiran, G. S., Gandhimathi, R. \& Priya, S. S. (2009). Culturable heterotrophic bacteria from the marine sponge Dendrilla nigra: isolation \& phylogenetic diversity of action bacteria. Helgoland Marine Research, 63: 239-247. https://doi.org/10.1007/s10152-009-0153-Z

Shah, K. R. (2012). FT-IR analysis of polyhydroxyalkanoates by novel Bacillus sp. AS 3-2 from soil of Kadi region, North Gujarat, India. Journal of Biochemical Technology, 3(4): 380-383.

Singh, P. \& Parmar, N., (2011). Isolation and characterization of two novel polyhydroxybutyrate (PHB) - producing bacteria. African Journal of Biotechnology, 10(24): 49074919.

Singla, N., Bansal, N., Gupta, V. \& Chander, J. (2013). Outbreak of Salmonella typhi enteric fever in sub-urban area of North India: a public health perspective. Asian Pacific Journal of Tropical Medicine, 6: 167-168. https://doi.org/10.1016/S1995-7645(13)60017-6

Sivaprakasam, S., Mahadevan, S., Sekar, S. \& Rajakumar, S. (2008). Biological treatment of tannery wastewater by using salt-tolerant bacterial strains. Microbial Cell Factories, 7: 15. https://doi.org/10.1186/1475-2859-7-15

Spiekermann, P., Rehm, B. \& Kalscheuer, R. (1999). A sensitive, viable-colony staining method using Nile red for direct screening of bacteria that accumulate polyhydroxyalkanoic acids and other lipid storage compounds. Archives of Microbiology, 71: 73-80. https://doi.org/10.1007/s002030050681

Tamdogan, N. \& Sidal, U. (2011). Investigation of Poly- $\beta$ Hydroxybutyrate (PHB) Production by Bacillus subtilis ATCC 6633 under different conditions. Kafkas Universitesi Veteriner Fakultesi Dergisi, 17(Supplement A): S173-S176. https://doi.org/10.9775/kvfd.2011.2474 
Tamura, K., Stecher, G., Peterson, D., Filipski, A. \& Kumar, S. (2013). MEGA6: Molecular evolutionary genetics analysis version 6.0. Molecular Biology and Evolution, 30: 2725-2729. https://doi.org/10.1093/molbev/mst197

Thomas, P. A. (1986). Demospongiae of the Gulf of Mannar and Palk Bay (pp. 205-365). In: James, P. S. B. R. (Ed.), Recent Advances in Marine Biology. New Delhi, India: Today and Tomorrow Printers and Publishers.

Valappil, S., Misra, S. \& Boccaccini, A. (2007). Large-scale production \& efficient recovery of $\mathrm{PHB}$ with desirable material properties, from the newly characterized Bacillus cereus SPV. Journal of Biotechnology, 132: 251258. https://doi.org/10.1016/j.jbiotec.2007.03.013
Velho-Pereira, S. \& Furtado, I. (2012). Antibacterial activity of halophilic bacterial bionts from marine invertebrates of Mandapam, India. Indian Journal of Pharmaceutical Sciences, 74(4): 331-338. https://doi.org/10.4103/0250-474x.107065

Wei, Y., Chen, W., Huang, C., Wu, H., Sun, Y., Lo, C. \& Janarthanan, O. (2011). Screening and Evaluation of Polyhydroxybutyrate- Producing Strains from Indigenous Isolate Cupriavidus taiwanensis Strains. International Journal of Molecular Sciences, 12(1): 252265. https://doi.org/10.3390/ijms12010252 